\title{
Occurrence of moulds from bee pollen in Central Italy - A preliminary study
}

\author{
Simona Nardoni ${ }^{1}$, Carlo D’Ascenzi ${ }^{1}$, Guido Rocchigiani' ${ }^{1}$, Valentina Moretti ${ }^{1}$, Francesca Mancianti ${ }^{1}$ \\ Dipartimento di Scienze Veterinarie, Università di Pisa, Pisa, Italy
}

Nardoni S, D'Ascenzi C, Rocchigiani G, Moretti V, Mancianti F. Occurrence of moulds from bee pollen in Central Italy - A preliminary study. Ann Agric Environ Med. 2016; 23(1): 103-105. doi: 10.5604/12321966.1196862

\begin{abstract}
The present study aimed to preliminary evaluate the occurrence of fungi in 40 specimens of trapped pollen collected from April - September 2015 in 40 apiaries from Tuscany (Central Italy). Cultural and microscopical examinations allowed the recognition of Cladosporium sp., Alternaria sp., Humicola sp. Mucoraceae and Acremonium sp. Penicillium brevicompactum, Penicillium chrysogenum, Aspergillus flavus, Aspergillus nidulans, Aspergillus niger and Aspergillus terreus were also identified. Yeasts and Fusarium spp. were not isolated. All pollen specimens were positive for at least one fungal isolate. Total CFU per gram ranged from 4-568. Aspergillus and Penicillium were obtained from 8 (20\%) and from 22 (55\%) pollen samples, respectively, associated in 4 cases (10\%). The recovery of storage fungi such as Aspergillus and Penicillium in trapped pollen presents a potential risk for human health and attention should be paid to all stages of the post-harvest process.
\end{abstract}

Key words

toxigenic fungi, bee pollen, moulds, Aspergillus, Penicillium

\section{INTRODUCTION}

Apiculture (beekeeping) is the practice of the management of honey bees in hives, principally for the honey and pollination (ecosystem services). Hives of bees also produce other products such as wax, royal jelly, propolis and pollen [1]. Bee pollen consists of plant pollens collected by worker bees combined with plant nectar. Field bees transport the bee pollen to the hive and usually store it as bee bread, compacted into the honeycomb cells, where it is used as food for all the colony drone bees. The beekeepers harvest bee pollen for human food by special traps where the foraging bees loose a part of bee pollen transported to colony. Bee pollen contains essential amino acids, vitamins, minerals, fats and oils, carbohydrates and antioxidants [2]. For these reasons, its use in the human diet is very highly appreciated; furthermore, it has been reported to have several therapeutic applications $[3,4,5]$.

There is growing concern about the sanitary quality of food. To meet the demand for bee-pollen and to prevent harm to consumer health, permanent controls in the beekeeping chain and the implementation of good production and processing practices by beekeepers and warehouses are essential [6].

Bees do not collect pollen from grass; however, they may occasionally collect fungal spores from mouldy plants [5] ando the occurrence of potentially toxigenic fungal species, as well as of mycotoxins, has been recorded [7, 8, 9, 10, 11].

To the best of the knowledge of the authors of this study, only few researchers have carefully investigated the mycological features of this substrate, and because of the lack of such information from Italy, the aim of the present study was a preliminary evaluation of the occurrence of fungi in samples of pollen obtained from Italian producers in Central Italy.

Address for correspondence: Simona Nardoni, viale delle Piagge 56124 Pisa, Italy E-mail: simona.nardoni@unipi.it

Received: 06 September 2015; accepted: 30 October 2015

\section{MATERIALS AND METHOD}

Forty specimens of trapped pollen were culturally examined for fungi. All the samples (50 grams) were collected from April - September 2015 in 40 apiaries from Tuscany (Central Italy). Trapped pollen was randomly collected by one beehive per apiary. In all cases, the traps were emptied daily and the samples of pollen placed in sterile plastic boxes, transported to a laboratory and processed within 24 hours.

Pollen aliquots of $5 \mathrm{~g}$ were diluted in $10 \mathrm{ml}$ of sterile saline and seeded onto Malt Extract Agar (MEA) plates, then maintained at $25^{\circ} \mathrm{C}$ for 10 days. All cultures were performed in triplicate. Colony forming units (CFU) per gram were calculated for each recovered fungi.

When required, subcultures on MEA and Czapeck-Dox agar for further identification were obtained. Fungal colonies were identified on the basis of their macro- and microscopic features $[12,13,14,15]$. Aspergillus and Penicillium were identified at species level.

\section{RESULTS}

Cultural and microscopical examinations allowed the recognition of Cladosporium sp., Alternaria sp., Humicola sp., Mucoraceae and Acremonium sp. Furthermore Penicillium brevicompactum, Penicillium chrysogenum, Aspergillus flavus, Aspergillus nidulans, Aspergillus niger and Aspergillus terreus were also identified. All pollen specimens were positive for at least one fungal isolate. Total CFU per gram were ranging from 4-568. Cladosporium sp. was the most frequently recovered mould (from 27 specimens), followed by $P$. chrysogenum (from 18 specimens).

Potentially toxigenic fungal species belonging to genera Aspergillus and Penicillium were obtained from 8 (20\%) and from $22(55 \%)$ pollen samples, respectively, in association in 4 cases $(10 \%)$. More detailed data about qualitative and quantitative mycological findings are shown in Table. 
Table 1. Qualitative and quantitative results of culture from pollen samples

\begin{tabular}{|c|c|}
\hline Sample & Fungal genera/species (Colony Forming Units per gram) \\
\hline 1 & Cladosporium sp. (50), Alternaria sp. (32) \\
\hline 2 & Alternaria sp.(61) \\
\hline 3 & Cladosporium sp. (38), Alternaria sp. (16) \\
\hline 4 & Penicillium chrysogenum (32) \\
\hline 5 & Penicillium chrysogenum (20) \\
\hline 6 & Cladosporium sp. (43) \\
\hline 7 & Cladosporium sp. (64), Humicola sp. (14) \\
\hline 8 & Aspergillus flavus (19) \\
\hline 9 & Aspergillus nidulans (8), Cladosporium sp. (47), Humicola sp. (12) \\
\hline 10 & Aspergillus niger (34), Cladosporium sp. (58), Humicola sp. (7) \\
\hline 11 & Alternaria sp. (44), Cladosporium sp. (43), Humicola sp. (4) \\
\hline 12 & Penicillium chrysogenum (79), Cladosporium sp. (65) \\
\hline 13 & Cladosporium sp. (30) \\
\hline 14 & Cladosporium sp. (64), Alternaria sp. (53) \\
\hline 15 & Penicillium brevicompactum (43) \\
\hline 16 & Penicillium brevicompactum (98), Cladosporium sp. (24) \\
\hline 17 & A. niger (21) \\
\hline 18 & Penicillium brevicompactum (24), Cladosporium sp. (12) \\
\hline 19 & Penicillium chrysogenum (61) \\
\hline 20 & Penicillium chrysogenum (72), Cladosporium (34) \\
\hline 21 & Penicillium chrysogenum (100), Cladosporium (24) \\
\hline 22 & Penicillium chrysogenum (231), Cladosporium (9) \\
\hline 23 & Penicillium chrysogenum (136) \\
\hline 24 & Penicillium chrysogenum (178), Penicillium brevicompactum (4) \\
\hline 25 & Cladosporium sp. (42), Penicillium brevicompactum (156) \\
\hline 26 & $\begin{array}{l}\text { Penicillium chrysogenum (172), Cladosporium sp.(36), Aspergillus terreus } \\
\text { (8) }\end{array}$ \\
\hline 27 & $\begin{array}{l}\text { Aspergillus niger (8), Penicillium chrysogenum ( 235), Alternaria sp.(8), } \\
\text { Cladosporium sp.(62) }\end{array}$ \\
\hline 28 & Aspergillus terreus (16), Penicillium chrysogenum (88) \\
\hline 29 & Alternaria sp (50), Cladosporium sp. (104) \\
\hline 30 & Penicillium chrysogenum (84) \\
\hline 31 & Cladosporium sp. (44), Penicillium chrysogenum (52) \\
\hline 32 & Acremonium sp. (48), Alternaria sp. (79), Cladosporium sp. (25) \\
\hline 33 & Penicillium chrysogenum (484) \\
\hline 34 & Mucoraceae (120), Cladosporium sp. (492), Alternaria sp. (278) \\
\hline 35 & Cladosporium sp. (428), Penicillium chrysogenum (544) \\
\hline 36 & Mucoraceae (143), Cladosporium sp. (344), Alternaria sp.(62) \\
\hline 37 & Cladosporium sp. (488) \\
\hline 38 & $\begin{array}{l}\text { Cladosporium sp.(404), Penicillium chrysogenum (486), Penicillium } \\
\text { brevicompactum (340) }\end{array}$ \\
\hline 39 & Penicillium chrysogenum (568), Aspergillus flavus (24) \\
\hline 40 & Cladosporium sp. (262), Mucoraceae (65) \\
\hline
\end{tabular}

\section{DISCUSSION}

The results of the presented study show the presence of moulds in all samples of the bee pollen examined. A few literature papers can be compared with our work. Penicillium spp., Aureobasidium sp. and Rhizopus sp. were reported as the dominant species in corbicular almond pollen from Arizona in the USA [7]. In Europe, Gonzales et al. [8] recovered Penicillium spp., Cladosporium spp., Aspergillus spp, Rhizopus spp. and Fusarium spp. from $89.9 \%, 90 \%, 80 \%$, $80 \%$ and $53.3 \%$ of specimens from commercially available bee pollen. In Slovakia, Mucoraceae, Fusarium sp., Aspergillus spp., Alternaria spp. and Paecilomyces spp. were isolated [16]. Furthermore cultures from differently treated pollen (frozen, dried and UV irradiated) in various areas of Slovakia yielded Mucoraceae, Alternaria, several Aspergillus species, Cladosporium cladosporioides and many Fusarium species [10]. Estevinho et al. [17] refer to the isolation of moulds and yeasts from $60 \%$ of specimens from Portuguese bee pollen. The data in the presented study regarding fungal genera are in general agreement with Gonzales et al., [8] and with Kakaniova et al. [10]. However, the results of the present survey differ from these authors in that Fusarium spp. was not isolated. Yeasts were also not isolated, although some authors $[6,8]$ report the occurrence of these fungi in $96.6 \%$ and $57.7 \%$ of bee pollen, respectively.

Bee pollen is reported as a substrate that stimulates mycotoxins' production [18] if the beekeeper does not provide adequate and prompt drying [19]. Hygiene measures on the pollen production chain, such as drying, can prevent mould growth and the possibility of mycotoxin biosynthesis. Hence, mycotoxins from Fusarium were identified from not properly dried pollen specimens [10, 11], and Gonzales et al. [8] demonstrated the occurrence of mycotoxin-producing fungi in bee pollen.

Values of humidity of freshly trapped pollen are usually low, ranging from $6.7 \%-20.6 \% \mathrm{RH}$, corresponding to a water activity $\left(a_{w}\right)$ of $0.3-0.7$. Storage conditions are very important for health and for the quality standards of pollen. Considering that minimal $\mathrm{a}_{\mathrm{w}}$ requirements of some common toxigenic moulds are near $0.70[20,21]$, the range of $a_{w}$ of fresh bee collected pollen includes compatible conditions for the growth of moulds and yeasts.

Toxigenic fungi are classified as field fungi and storage fungi [22]. Fusarium is the main toxigenic field fungal genus, while Aspergillus and Penicillium are storage fungi. In the presented study, the lack of isolation of Fusarium from fresh untreated bee pollen is striking, and could suggest a low environmental occurrence of these fungi. Conversely, the presence of both Aspergillus and Penicillium suggests that attention should be paid to all stages of the post-harvest process. A further step will be the investigation of contamination by mycotoxins in bee pollen from Italy.

In conclusion, the recovery of storage fungi such as Aspergillus and Penicillium in trapped pollen presents a potential risk for human health, and attention should be paid to all stages of the post-harvest process. 


\section{REFERENCES}

1. Formato G, Smulders FJ. Risk management in primary apicultural production. Part 1: bee health and disease prevention and associated best practices. Vet Q. 2011; 31(1): 29-47.

2. Campos MGR, Stefan Bogdanov S, Bicudo de Almeida-Muradian L, Szczesna T, Mancebo Y, Frigerio C, Ferreira F. Pollen composition and standardization of analytical methods. J Apic Res. 2008; 47(2): 156-163.

3. Fatrcová-Šramková K, Nôžková J, Kačániová M, Máriássyová M, Rovná K, Stričík M. Antioxidant and antimicrobial properties of monofloral bee pollen. J Environ Sci Health. 2013; 48(2): 133-138.

4. Pascoal A, Rodrigues S, Teixeira A, Feás X, Estevinho LM. Biological activities of commercial bee pollens: antimicrobial, antimutagenic, antioxidant and anti-inflammatory. Food Chem Toxicol. 2014; 63: 233-239.

5. Komosinska-Vassev K, Olczyk P, Kaźmierczak J, Mencner L, Olczyk K. Bee Pollen: Chemical Composition and Therapeutic Application. 2015; doi: 10.1155/2015/297425.

6. De-Melo AA, Estevinho ML, de Almeida-Muradian LB. A diagnosis of the microbiological quality of dehydrated bee-pollen produced in Brazil. Lett Appl Microbiol. 2015; doi: 10.1111/lam.12480. [Epub ahead of print].

7. Gilliam M, Prest DB, Prest DB, Lorenz BJ, Lorenz BJ. Microbiology of pollen and bee bread: taxonomy and enzymology of molds. Apidol. 1989; 20: 53-68.

8. González G, Hinojo MJ, Mateo R, Medina A, M. Jiménez AM. Occurrence of mycotoxin producing fungi in bee pollen. Int J Food Microbiol. 2005; 105: 1-9.

9. Kacániová M, Pavlicová S, Hascík P, Kociubinski G, Kńazovická V, Sudzina M, Sudzinová J, Fikselová M. Microbial communities in bees, pollen and honey from Slovakia. Acta Microbiol Immunol Hung. 2009; 56(3): 285-295.

10. Kačániová M, Juráček M, Chlebo R, Kňazovická V, Kadasi-Horáková M, Kunová S, Lejková J, Haščík P, Mareček J, Simko M. Mycobiota and mycotoxins in bee pollen collected from different areas of Slovakia. J Environ Sci Health B. 2011; 46(7): 623-629.

11. Rodríguez-Carrasco Y, Font G, Mañes J, Berrada H. Determination of mycotoxins in bee pollen by gas chromatography-tandem mass spectrometry. J Agric Food Chem. 2013; 61: 1999-2005.

12. Raper KB, Fennell DI. The genus Aspergillus. 1st ed. Baltimore (MD) Publisher Williams \& Wilkins, 1965.

13. Pitt JI. The genus Penicillium and its teleomorphic states Eupenicillium and Talaromyces. 1st ed. London Academic Press Inc, 1979.

14. De Hoog GS, Guarro J, Figueras MJ, Gené, J. Atlas of Clinical Fungi. 2nd ed. Centraalbureau voor Schimmelcultures, Utrecht, The Netherlands and Universitat Rovira i Virgili, Reus, Spain, 2000.

15. Samson RA, Hoekstra ES, Frisvad JC. Introduction to food-borne fungi. 7th ed. Centraalbureau voor Schimmelcultures Baarn Delft, 2004.

16. Brindza J, Gróf J, Bacigálová K, Ferianc P, Tóth D. Pollen microbial colonization and food safety. Acta Chim Slov. 2013; 3: 95-102.

17. Estevinho LM, Rodrigues S, Pereira AP, Feás X. Portuguese bee pollen: palynological study, nutritional and microbiological evaluation. Int J Food Sci Tech. 2012; 47: 429-435.

18. Medina A, González G, Sáez JM, Mateo R, Jiménez M. Bee pollen, a substrate that stimulates ochratoxin A production by Aspergillus ochraceus Wilh. Syst Appl Microbiol. 2004; 27: 261-267.

19. Garcia-Villanova RJ, Cordón C, González Paramás AM, Aparicio P, Garcia Rosales ME. Simultaneous immunoaffinity column cleanup and HPLC analysis of aflatoxins and ochratoxin A in Spanish bee pollen. J Agric Food Chem. 2004; 52: 7235-7239.

20. Collin S, Vanhavre T, Bodart E, Bouseta A. Heat treatment of pollens: impact on their volatile flavor constituents. J Agric Food Chem. 1995; 43: 444-448.

21. Bhat R, Rai RV, Karim AA. Mycotoxins in food and feed: present status and future concerns. Compr Rev Food Sci Food Safety. 2010; 9: 57-81.

22. Logrieco A. and Visconti A. An overview on toxigenic fungi and mycotoxins in Europe. 1st ed. Kluwer Academic Publishers, Dordrecht, The Netherlands, 2004. 